\title{
Pengaruh Perkembangan Bandara Internasional Adi Soemarmo terhadap Perubahan Guna Lahan Perdagangan dan Jasa Pada Koridor Jalan Adi SUCIPTO di Kota SURAKarta - KabUPATEN KARANGANYAR
}

\author{
Fitri Nur Cahyani, Winny Astuti, Galing Yudana \\ Program Studi Perencanaan Wilayah Dan Kota \\ Fakultas Teknik \\ Universitas Sebelas Maret, Surakarta \\ email: fitrinurcahyani95@gmail.com
}

\begin{abstract}
Adi Soemarmo International Airport is one of the terminal air transportation, which is currently being carried out development. Empirically, Adi Soemarmo International Airport have a direction towards the development of Surakarta is a corridor that connects the Adi Soemarmo International Airport with the city center of Surakarta. One of the corridors that developed along the development of Adi Soemarmo International Airport is an Adi Sucipto road corridor. Development in Adi Sucipto road corridor are emerging land use of commercial activities. The problem in this research is how to influence the development of Adi Soemarmo International Airport to changes in land use of trade and services in the Adi Sucipto road corridor? The purpose of research is influence the development of Adi Soemarmo International Airport to changes in land use of trade and services in the corridor of Adi Sucipto road corridor. The method used is the deductive research methods with quantitative research. The analysis technique used is descriptive analysis. Conclusions from this research is the development of Adi Soemarmo International Airport influence to changes in land use of trade and services in the corridor of Adi Sucipto road corridor. The degree of influence can be divided into three classifications that is high levels of influence, medium levels of influence, and low levels of influence. High levels of influence, that is (1) the influence of the facility of Adi Soemarmo International Airport to function of land use and floor space ratio of trade and service in the corridor of Adi Sucipto road. (2) the influence of of the accessibility of Adi Soemarmo International Airport to function of land use and floor space ratio of trade and service in the corridor of Adi Sucipto road.
\end{abstract}

Keywords: airport, road corridor, land use

\section{PENDAHULUAN}

Bandar udara merupakan salah satu terminal moda transportasi yang mempunyai dampak pada wilayah sekitarnya termasuk pada jaringan yang menghubungkan antara bandar udara dengan pusat kegiatan, dimana pada jaringan yang menghubungkan tersebut menjadi wilayah yang lebih strategis. Bandar udara juga mampu mendorong perkembangan sebuah kota dalam koridor yang menghubungkan antara bandar udara dengan pusat kota. Karena pada koridor ini mempunyai wilayah yang potensial dalam aksesibilitas dan integrasi antar wilayah (Schaafsma dalam Knippenberger dan Wall, 2010).

Perkembangan pada area sekitar bandar udara yang terjadi cenderung pada kawasan perdagangan dan jasa, maka dari itu orientasi pembangunan lebih mengarah pada sektor bisnis dan perdagangan dan jasa. Terdapat dua orientasi penting terkait penggunaan lahan, yaitu perkembangan kawasan perdagangan dan jasa dan pertumbuhan kota yang lebih luas (Kasarda dan Appold, 2014).

Sebuah bandar udara berkembang dikarenakan adanya pelayanan moda transportasi udara, pengguna moda transportasi udara, kegiatan bisnis yang menyediakan tambahan kebutuhan bagi pengunjung dan pekerja, serta perusahaan yang mengakomodasi akses dengan mudah. Bandar udara juga mempunyai daya tarik tersendiri dalam pembangunan kawasan perdagangan dan jasa, daya tarik ini akibat adanya kegiatan yang meningkat pada bandar udara (Kasarda 2010).

Salah satu bandar udara yang saat ini telah melakukan pengembangan untuk memajukan layanan jasa transportasi udara yaitu Bandara Internasional Adi Soemarmo yang merupakan salah satu bandar udara 
internasional. Hal ini didukung dengan pengembangan Bandara Internasional Adi Soemarmo pada tahun 2009 yaitu dilakukannya pengembangan dengan penambahan terminal penerbangan. Pengembangan bandar udara ini terjadi secara menyeluruh, dan merupakan kelanjutan pembangunan Bandara Internasional Adi Soemarmo yang sebelumnya sudah dilakukan pembangunan namun terhenti.

Bandara Internasional Adi Soemarmo merupakan salah satu bandar udara yang terletak di Kabupaten Boyolali, namun karena letak bandar udara dekat dengan Kota Surakarta dan dalam pengembangannya lebih erat kaitannya dengan Kota Surakarta maka lebih dikenal dengan sebutan Bandara Internasional Surakarta, bukan sebagai Bandara Internasional Boyolali.

Wilayah sekitar bandar udara mengalami perkembangan wilayah secara luas misalnya tumbuhnya fasiltas-fasilitas perdagangan dan jasa. Secara empiris, koridor Jalan Adi Sucipto mengalami perkembangan terkait sarana perhotelan, guest house, restoran, dan sarana perdagangan \& jasa lainnya. Pada koridor Jalan Adi Sucipto juga merupakan koridor yang letaknya dekat dengan Bandara Internasional Adi Soemarmo.

Perkembangan kegiatan yang berada pada kawasan bandar udara yang berdampak pada berkembangnya fasilitas pendukung kegiatan penerbangan maupun non-penerbangan akan berpengaruh pada guna lahan sekitarnya khususnya guna lahan perdagangan dan jasa, karena kawasan bandar udara menciptakan sebuah kegiatan yang akan mempengaruhi perubahan guna lahan. Berdasarkan berkembangnya kegiatan penerbangan dan non-penerbangan pada Bandara Internasional Adi Soemarmo serta perubahan penggunaan lahan pada koridor bandar udara dengan pusat Kota Surakarta (Jalan Adi Sucipto), maka rumusan masalah dalam penelitian ini adalah:

"Bagaimana pengaruh perkembangan Bandara Internasional Adi Soemarmo terhadap perubahan guna lahan perdagangan dan jasa pada koridor Jalan Adi Sucipto?"

\section{TINJAUAN PUSTAKA}

Tinjauan literatur merupakan suatu tinjauan yang dilakukan dengan berbagai literatur yang relevan dengan penelitian yaitu pengaruh perkembangan Bandara
Internasional Adi Soemarmo terhadap perubahan guna lahan perdagangan dan jasa pada koridor Jalan Adi Sucipto.

\subsection{Perkembangan Bandara}

Menurut Kamus Besar Bahasa Indonesia (KBBI), perkembangan merupakan suatu perihal berkembang. Berkembang diartikan dengan beberapa definisi sebagai berikut: 1) mekar terbuka atau membentang (tentang barang yang berlipat); 2) menjadi besar (luas, banyak); 3) menjadi bertambah sempurna; 4) menjadi banyak (merata, meluas).

Bandara adalah suatu kawasan yang berada di suatu daratan maupun lautan yang mempunyai batas-batas tertentu yang digunakan sebagai tempat pesawat udara untuk lepas landas dan mendarat, naik dan turun penumpang, serta perpindahan intra dan antar moda transportasi yang dilengkapi fasilitas keselamatan, keamanan penerbangan serta fasilitas pokok dan penunjang lainnya (UU No. 1 tahun 2009 tentang Penerbangan).

\subsubsection{Bandara dalam Konsep Airport Corridor}

Dalam theoretical corridors, poin utama yang terpengaruh yaitu terkait dengan peningkatan infrastruktur, aksesibilitas, penggunaan lahan serta terhadap kebijakan (Markus Hesse dalam Knippenberger 2010)

Airport Corridor merupakan suatu koridor bandara yang menghubungkan antara sebuah bandara dengan pusat kota, dimana dalam perkembangannya koridor ini menjadi wilayah yang terdampak dari perkembangan bandara sendiri. Wilayah koridor ini menjadi strategis dengan adanya dampak dari pembangunanpembangunan yang terjadi pada bandara (Schlaack dalam Knippenberger 2010). Gambar Airport Corridor Concept dapat dilihat pada gambar di bawah ini.

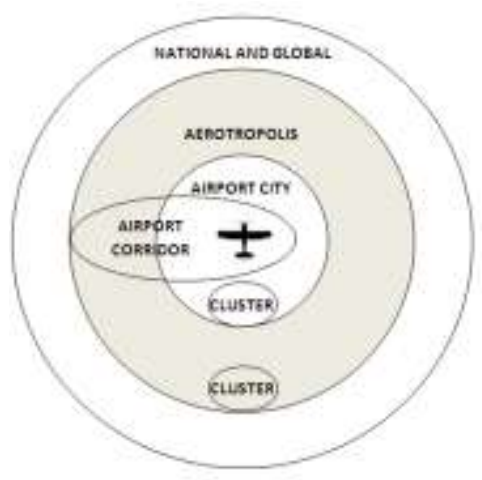


Gambar 1. Airport Corridor Concept (Yigitcanlar et al. 2008 dalam Peneda, Reis, and Macário 2010)

Perkembangan bandara dapat dipengaruhi oleh volume pergerakan orang dan karyawan yang mendukung pergerakan tersebut. Karyawan tersebut bekerja pada sektor perhotelan, layanan jasa bandara dan wisatawa. Beberapa karyawan pada sektor yang mendukung kegiatan layanan jasa transportasi udara (Erie et al 1999 dalam Kasarda dan Lindsay 2011).

Perkembangan bandara akan mempengaruhi perkembangan perkembangan komersial yang didorong salah satunya oleh pergerakan penumpang. Pengaruh lain juga pada pada hal aksesibilitas yaitu digunakan untuk efisiensinya pergerakan penumpang (wisatawan, pekerja). Wisatawan bisnis mempunyai keuntungan dalam hal aksesibilitas, yaitu: pilihan terbaik untuk menggunakan jasa transportasi udara, flexibel dalam penataan jadwal kembali juga membantu wisatawan dalam menghemat biaya. Dalam perkembangannya, penempatan fasilitas berada pada koridor bandara (Kasarda 2010).

Perkembangan sebuah bandara dapat memicu beberapa hal yaitu pertumbuhan ekonomi wilayah, pertumbuhan bisnis aviation dan perkembangan area bandara (konektivitas, pergerakan orang, serta penggunaan lahan). Hal tersebut diketahui bahwa perkembangan bandara akan mendorong perkembangan dan perubahan guna lahan pada area sekitar bandara (Kasarda \& Appold, 2014)

\subsubsection{Bandara sebagai Sistem Transportasi}

Menurut Manheim (1979) dalam Widayanti 2010, dalam sistem transportasi makro terdapat tiga variabel yang akan mempengaruhi perkembangan bandara yang saling berkaitan dan berpengaruh satu sama lain yaitu sistem transportasi, sistem kegiatan, dan pola pergerakan.

Menurut Tamin (2000), sistem transportasi makro terdiri dari sistem kegiatan, sistem jaringan dan sistem pergerakan.

Perkembangan bandara dapat ditunjang dengan sarana dan prasaran yang menunjang kegiatan bandara, sistem kegiatan, dan pola atau intensitas pergerakan (Manhein, 1979 dalam Widayanti 2010).

\subsection{Perubahan Guna Lahan}

Tata guna lahan merupakan pengaturan guna lahan mengenai guna lahan yang ada di wilayah darat maupun dalam wilayah lautan (Jayadinata, 1999).

Perubahan guna lahan merupakan bertambahnya suatu penggunaan lahan dari satu sisi penggunaan ke penggunaan yang lainnya diikuti dengan berkurangnya tipe penggunaan lahan yang lain dari suatu waktu, atau berubahnya fungsi suatu lahan pada kurun waktu yang berbeda (Martin, 1993 dalam Eko dan Rahayu 2012).

Menurut Wahyunto dkk 2001 dalam Widayanti 2010, perubahan guna lahan adalah berubahnya fungsi lahan pada kurun waktu tertentu. Perubahan lahan diikuti dengan perubahan atau berkurangnya suatu jenis penggunaan lahan ke penggunaan lahan yang lainnya.

Menurut Bakar 2008, penggunaan ruang yang berkaitan dengan rencana tata ruang, terdapat tiga jenis perubahan yang terjadi, yaitu perubahan fungsi, perubahan intensitas dan perubahan persyaratan teknis bangunan.

\section{METODE PENELITIAN}

\subsection{Ruang Lingkup}

Ruang lingkup wilayah penelitian ini yaitu Bandara Internasional Adi Soemarmo dan koridor Jalan Adi Sucipto. Hal ini didasari oleh perkembangan bandara yang berdampak pada koridor jalan yang menghubungkan bandara dengan pusat kota (kegiatan) dalam konsep airport corridor. Ruang lingkup pembahasannya yaitu konsep airport corridor, perkembangan bandara dan perubahan guna lahan. Peta ruang lingkup wilayah penelitian dapat dilihat pada Lampiran 1.

\subsection{Metode Analisis}

Metode pendekatan yang digunakan dalam penelitian ini yaitu metode pendekatan deduktif. Jenis penelitian yang digunakan dalam penelitian ini yaitu jenis penelitian kuantitatif.

\subsection{Variabel Penelitian}

Variabel merupakan suatu hal yang digunakan sebagai ciri atau ukuran dalam sebuah penelitian. Variabel dan indikator penelitian dapat dilihat pada Lampiran 2. 


\subsection{Teknik Pengumpulan Data}

Teknik pengumpulan data yang dilakukan dalam penelitian ini terbagi menjadi dua yaitu teknik pengumpulan data primer dan teknik pengumpulan data sekunder. Data primer didapatkan secara langsung pada wilayah kajian yaitu wawancara kepada PT. Angkasa Pura I dan observasi lapangan pada guna lahan di koridor Jalan Adi Sucipto. Data sekunder didapatkan melalui instansi terkait data yang dibutuhkan yaitu PT. Angkasa Pura I, Badan Pertanahan Nasional Kota Surakarta, serta Dinas Pengelolaan Pendapatan Keuangan dan Aset Daerah Kabupaten Karanganyar.

\subsection{Teknik Analisis}

Teknik analisis yang digunakan dalam penelitian ini adalah teknik analisis deskriptif, dalam analisis deskriptif ini sebelumnya variabel dianalisis untuk diklasifikasikan berdasarkan indikator seperti pada Matriks Operasional Variabel. Variabel yang sudah diklasifikasikan kemudian disilangkan untuk mengetahui tingkat pengaruh antar dua variabel. Persilangan variabel tersebut kemudian didapatkan hasil persilangan untuk mengetahui bagaimana tingkat pengaruh kedua variabel. Tingkat pengaruh perkembangan bandara dengan perubahan guna lahan dapat dilihat pada Tabel 1 di bawah ini.

Tabel 1. Tingkat Pengaruh Perkembangan Bandara dengan Perubahan Guna Lahan

\begin{tabular}{|l|l|l|l|l|}
\hline $\begin{array}{l}\text { Nilai } \\
\text { Perkembangan } \\
\text { Bandara }\end{array}$ & $\begin{array}{l}\text { Nilai } \\
\text { Perubahan } \\
\text { Guna } \\
\text { Lahan }\end{array}$ & $\begin{array}{l}\text { Nilai } \\
\text { Silang }\end{array}$ & $\begin{array}{l}\text { Tingkat } \\
\text { Pengaruh }\end{array}$ & $\begin{array}{l}\text { Nilai } \\
\text { Pengaruh }\end{array}$ \\
\hline \multirow{5}{*}{1} & 1 & 1.1 & Tinggi & 3 \\
\cline { 2 - 5 } & 2 & 1.2 & Sedang & 2 \\
\cline { 2 - 5 } & 3 & 1.3 & Rendah & 1 \\
\hline 2 & 1 & 2.1 & Sedang & 2 \\
\cline { 2 - 5 } & 2 & 2.2 & Tinggi & 3 \\
\cline { 2 - 5 } & 3 & 2.3 & Sedang & 2 \\
\hline 3 & 1 & 3.1 & Rendah & 1 \\
\cline { 2 - 5 } & 2 & 3.2 & Sedang & 2 \\
\cline { 2 - 5 } & 3 & 3.3 & Tinggi & 3 \\
\hline
\end{tabular}

\section{HASIL PENELITIAN}

Dari hasil analisis, didapatkan 9 (sembilan) hasil pengaruh pada setiap variabel dalm pengaruh perkembangan Bandara Internasional Adi Soemarmo terhadap perubahan guna lahan perdagangan dan jasa pada koridor Jalan Adi Sucipto yaitu sebagai berikut:
4.1 Pengaruh Perkembangan Fasilitas Bandara Internasional Adi Soemarmo terhadap Perubahan Fungsi Guna Lahan Perdagangan dan Jasa pada Koridor Jalan Adi Sucipto.

Perkembangan fasilitas bandara masuk dalam klasifikasi perkembangan sedang, hal tersebut dikarenakan fasilitas bandara yang mengalami perkembangan tidak mencakup semua fasilitas melainkan beberapa fasilitas di antaranya fasilitas dari sisi darat. Fungsi guna lahan mengalami perubahan sebesar $43 \%$, hal tersebut menyebabkan perubahan fungsi masuk dalam klasifikasi perubahan sedang. Berdasarkan hal tersebut perkembangan fasilitas Bandara Internasional Adi Soemarmo mempunyai pengaruh tinggi terhadap perubahan fungsi guna lahan perdagangan dan jasa pada koridor Jalan Adi Sucipto.

4.2 Pengaruh Perkembangan Fasilitas Bandara Internasional Adi Soemarmo terhadap Perubahan Koefisien Dasar Bangunan (KDB) Guna Lahan Perdagangan dan Jasa pada Koridor Jalan Adi Sucipto.

Perkembangan fasilitas di Bandara Internasional Adi Soemarmo tidak mencakup semua fasilitas melainkan beberapa fasilitas bandara dari sisi darat, berdasarkan hal tersebut klasifikasi perkembangan bandara masuk dalam klasifikasi perkembangan sedang. Persentase perubahan koefisien dasar bangunan (KDB) sebesar 23,8\%, hal tersebut menyebabkan klasifikasi perubahan koefisien dasar bangunan (KDB) masuk dalam klasifikasi rendah. Berdasarkan hal tersebut, perkembangan fasilitas Bandara Internasional Adi Soemarmo mempunyai pengaruh sedang terhadap perubahan koefisien dasar bangunan (KDB) guna lahan perdagangan dan jasa pada koridor Jalan Adi Sucipto.

4.3 Pengaruh Perkembangan Fasilitas Bandara Internasional Adi Soemarmo terhadap Perubahan Koefisien Lantai Bangunan (KLB) Guna Lahan Perdagangan dan Jasa pada Koridor Jalan Adi Sucipto.

Fasilitas bandara mempunyai klasifikasi perkembangan sedang dengan berkembangnya fasilitas bandara pada sisi darat, untuk fasilitas bandara dari sisi udara mayoritas tidak mengalami perkembangan. Terjadi perubahan 
koefisien lantai bangunan (KLB) sebesar 46\%, hal tersebut menyebabkan perubahan koefisien lantai bangunan masuk dalam klasifikasi sedang. Berdasarkan hal tersebut perkembangan fasilitas Bandara Internasional Adi Soemarmo mempunyai pengaruh tinggi terhadap perubahan koefisien lantai bangunan (KLB) guna lahan perdagangan dan jasa pada koridor Jalan Adi Sucipto.

\subsection{Pengaruh Perkembangan Aksesibilitas} Bandara Internasional Adi Soemarmo terhadap Perubahan Fungsi Guna Lahan Perdagangan dan Jasa pada Koridor Jalan Adi Sucipto.

Adanya perkembangan aksesibilitas dengan perkembangan moda transportasi yang terintegrasi dengan bandara yaitu moda bus dengan menghubungkan berbagai sarana transporasi yang berada pada wilayah sekitar bandara. Hal tersebut menyebabkan perkembangan aksesibilitas bandara masuk dalam klasifikasi sedang. Perubahan fungsi guna lahan masuk dalam klasifikasi perubahan sedang dengan persentase perubahan sebesar $43 \%$. Berdasarkan hal tersebut, perkembangan aksesibilitas Bandara Internasional Adi Soemarmo mempunyai pengaruh tinggi terhadap perubahan fungsi guna lahan perdagangan dan jasa pada koridor Jalan Adi Sucipto.

\subsection{Pengaruh Perkembangan} Aksesibilitas Bandara Internasional Adi Soemarmo terhadap Perubahan Koefisien Dasar Bangunan (KDB) Guna Lahan Perdagangan dan Jasa pada Koridor Jalan Adi Sucipto.

Aksesibilitas bandara mengalami perkembangan dengan teringrasinya bandara dengan moda transportasi bus, maka perkembangan aksesibilitas bandara masuk dalam klasifikasi perkembangan sedang. Perubahan koefisien dasar bangunan masuk dalam klasifikasi rendah dengan persentase perubahan sebesar 23,8\%. Berdasarkan hal tersebut, perkembangan aksesibilitas Bandara Internasional Adi Soemarmo mempunyai pengaruh sedang terhadap perubahan koefisien dasar bangunan (KDB) guna lahan perdagangan dan jasa pada koridor Jalan Adi Sucipto.
4.6 Pengaruh $\quad$ Perkembangan

Aksesibilitas Bandara Internasional Adi Soemarmo terhadap Perubahan Koefisien Lantai Bangunan (KLB) Guna Lahan Perdagangan dan Jasa pada Koridor Jalan Adi Sucipto.

Perkembangan aksesibilitas dilihat dari perkembangan akses transportasi atau terintegrasinya bandara dengan layanan multimoda. Perkembangan terjadi pada berkembangnya moda transportasi bus yang terintegrasi dengan bandara. Hal tersebut menyebabkan klasifikasi perkembangan aksesibilitas masuk dalam perkembangan sedang. Persentase perubahan koefisien lantai bangunan (KLB) mengalami perkembangan sebesar $46 \%$ denganklasifikasi perubahan sedang. Berdasarkan hal tersebut, perkembangan aksesibilitas Bandara Internasional Adi Soemarmo mempunyai pengaruh tinggi terhadap perubahan koefisien lantai bangunan (KLB) guna lahan perdagangan dan jasa pada koridor Jalan Adi Sucipto.

4.7 Pengaruh Perkembangan Intensitas Pergerakan Bandara Internasional Adi Soemarmo terhadap Perubahan Fungsi Guna Lahan Perdagangan dan Jasa pada Koridor Jalan Adi Sucipto.

Intensitas pergerakan dilihat dari rute perjalanan yang ditawarkan dari bandara, berdasarkan data rute perjalanan mengalami peningkatan. Hal tersebut menyebabkan terjadinya perkembangan intensitas pergerakan dengan klasifikasi tinggi. Persentase perubahan fungsi guna lahan sebesar $43 \%$ dan masuk dalam klasifikasi perkembangan sedang. Berdasarkan hal tersebut, perkembangan intensitas pergerakan Bandara Internasional Adi Soemarmo mempunyai pengaruh sedang terhadap perubahan fungsi guna lahan perdagangan dan jasa pada koridor Jalan Adi Sucipto.

4.8 Pengaruh Perkembangan Intensitas Pergerakan Bandara Internasional Adi Soemarmo terhadap Koefisien Dasar Bangunan (KDB) Perubahan Guna Lahan Perdagangan dan Jasa pada Koridor Jalan Adi Sucipto.

Perkembangan intensitas masuk dalam klasifikasi tinggi dengan adanya peningkatan rute perjalanan. Koefisien dasar bangunan 
(KDB) mengalami perubahan dengan persentase perubahan sebesar $23,8 \%$ dan masuk dalam klasifikasi rendah. Berdasarkan hal tersebut, perkembangan intensitas pergerakan Bandara Internasional Adi Soemarmo mempunyai pengaruh rendah terhadap koefisien dasar bangunan (KDB) perubahan guna lahan perdagangan dan jasa pada koridor Jalan Adi Sucipto.

\subsection{Pengaruh Perkembangan Intensitas Pergerakan Bandara Internasional Adi Soemarmo terhadap Koefisien Lantai Bangunan (KLB) Perubahan Guna Lahan Perdagangan dan Jasa pada Koridor Jalan Adi Sucipto.}

Perkembangan intensitas bandara mengalami perkembangan dengan berkembangnya rute perjalanan baik dari perjalanan domestik maupun internasional. Hal tersebut menyebabkan perkembangan intensitas pergerakan masuk dalam klasifikasi perkembangan tinggi. Koefisien lantai bangunan (KLB) mengalami perkembangan dengan persentase perubahan sebesar $46 \%$ dan masuk klasifikasi perkembangan sedang. Berdasarkan hal tersebut, perkembangan intensitas pergerakan Bandara Internasional Adi Soemarmo mempunyai pengaruh sedang terhadap koefisien lantai bangunan (KLB) perubahan guna lahan perdagangan dan jasa pada koridor Jalan Adi Sucipto.

\section{KESIMPULAN}

Berdasarkan penelitian yang telah dilakukan, diketahui 3 (tiga) tingkat pengaruh yaitu pengaruh rendah, pengaruh sedang, dan pengaruh tinggi terkait judul penelitian pengaruh perkembangan Bandara Internasional Adi Soemarmo terhadap perubahan guna lahan perdagangan dan jasa pada koridor Jalan Adi Sucipto.

Perkembangan fasilitas Bandara Internasional Adi Soemarmo berpengaruh tinggi terhadap perubahan fungsi dan perubahan Koefisien Lantai Bangunan (KLB) guna lahan perdagangan dan jasa pada koridor Jalan Adi Sucipto serta berpengaruh sedang terhadap perubahan Koefisien Dasar Bangunan (KDB) guna lahan perdagangan dan jasa pada koridor Jalan Adi Sucipto. Perkembangan aksesibilitas Bandara Internasional Adi Soemarmo berpengaruh tinggi terhadap perubahan fungsi dan perubahan Koefisien Lantai Bangunan (KLB) guna lahan perdagangan dan jasa pada koridor Jalan Adi Sucipto serta berpengaruh sedang terhadap perubahan Koefisien Dasar Bangunan (KDB) guna lahan perdagangan dan jasa pada koridor Jalan Adi Sucipto. Perkembangan intensitas pergerakan Bandara Internasional Adi Soemarmo berpengaruh sedang terhadap perubahan fungsi dan perubahan Koefisien Lantai Bangunan (KLB) guna lahan perdagangan dan jasa pada koridor Jalan Adi Sucipto serta berpengaruh rendah terhadap perubahan Koefisien Dasar Bangunan (KDB) guna lahan perdagangan dan jasa pada koridor Jalan Adi Sucipto.

\section{REFERENSI}

- Kamus Besar Bahasa Indonesia. http://kbbi.web.id/kembang. Diakses pada 25 November 2016.

Bakar, Sofjan. 2008. Kelembagaan Pengendalian Pemanfaatan Ruang di Daerah. $\quad$ http://tataruang.atrbpn.go.id/Bulletin/index.asp?mod=_full art\&idart $=90 . \quad$ Diakses pada 02 Desember 2016.

Eko, Trigus, dan Sri Rahayu. 2012. Perubahan Penggunaan Lahan dan Kesesuaiannya terhadap RDTR di Wilayah Peri-Urban Studi Kasus: Kecamatan Mlati. Semarang: Biro Penerbit Planologi Undip.

Jayadinata, Johara T., 1999. Tata Guna Tanah dalam Perencanaan Pedesaan Perkotaan \& Wilayah. Bandung: Penerbit ITB.

Kasarda, J. D., dan S.J. Appold. 2014. Planning A Competitive Aerotropolis. West Yorkshire: Emerald Group Publishing.

Kasarda, J. D., dan G. Lindsay. 2011. Aerotropolis: The Way We'll Live Next. United States: Mcmillan.

Kasarda, J. D. 2010. Global Airport City. United Kingdom: Insight Media.

Knippenberger, Wall, eds. 2010. Airports in Cities and Regions Research and Practise. Deutshland: KIT Scientific Publishing.

Peneda, M.J.A., Vasco Domingos Reis, and Maria do Rosário M.R. Macário. 2010. Critical Factors for the Development of Airport Cities. Portugal: Universidade Técnica de Lisboa. 
UU No. 1 tahun 2009 tentang Penerbangan.

Tamin, Ofyar Z. 2000. Perencanaan dan Pemodelan Transportasi. Edisi kedua, Bandung: Penerbit ITB.

Widayanti, Rina. 2010. Formulasi Model Pengaruh Perubahan Tata Guna Lahan terhadap Angkutan Kota di Kota Depok. Depok: Universitas Gunadharma.

Zahnd, Markus. 1999. Perancangan Kota Secara Terpadu. Yogyakarta : Penerbit Kanisius. 



\section{LAMPIRAN 1}

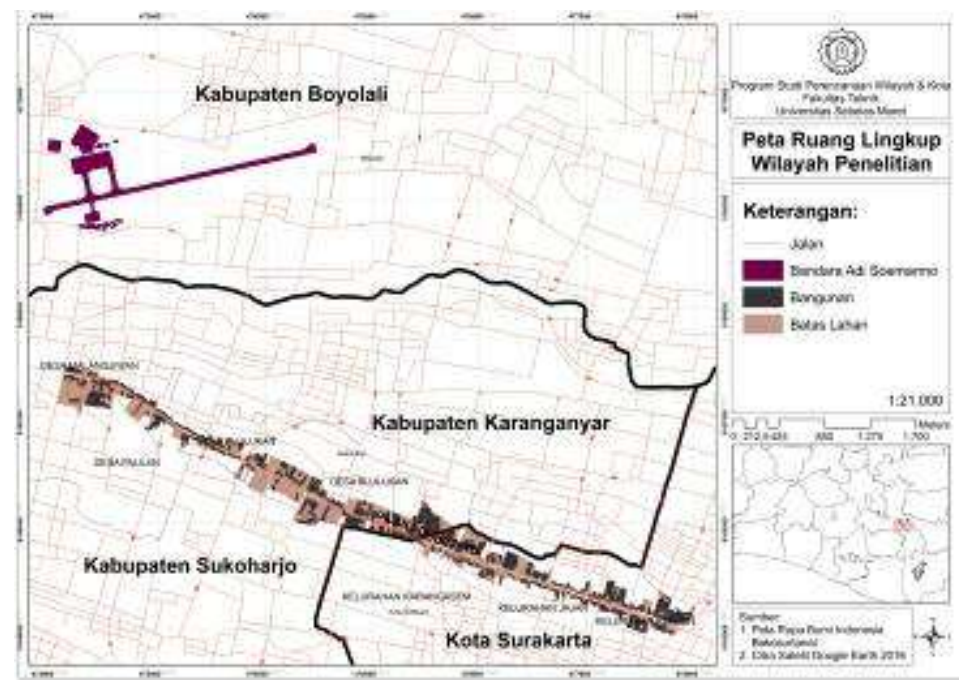

Lampiran 1. Peta Ruang Lingkup Wilayah Surakarta

\section{LAMPIRAN 2}

Lampiran 2. Tabel Matriks Operasional Variabel

\begin{tabular}{|c|c|c|c|c|c|c|}
\hline \multirow{2}{*}{$\begin{array}{c}\text { Varia } \\
\text { bel }\end{array}$} & \multirow[t]{2}{*}{ Sub Variabel } & \multirow[t]{2}{*}{ Indikator } & \multicolumn{3}{|l|}{ Parameter } & \multirow[t]{2}{*}{ Sumber } \\
\hline & & & \multirow{7}{*}{$\begin{array}{l}\text { Rendah } \\
\text { Apabila nilai } \\
\text { Fasilitas antara } \\
6-9\end{array}$} & Sedang & Tinggi & \\
\hline \multirow{8}{*}{ 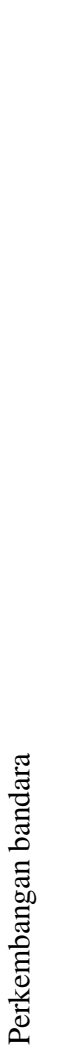 } & \multirow[t]{6}{*}{$\begin{array}{l}\text { Perkembangan } \\
\text { fasilitas bandara }\end{array}$} & $\begin{array}{l}\text { Perkembangan } \\
\text { runway }\end{array}$ & & \multirow[t]{6}{*}{$\begin{array}{l}\text { Apabila nilai } \\
\text { Fasilitas } 10-13\end{array}$} & \multirow[t]{6}{*}{$\begin{array}{l}\text { Apabila nilai } \\
\text { Fasilitas } 14-18\end{array}$} & \multirow{6}{*}{$\begin{array}{l}\text { Peraturan } \\
\text { Direktorat } \\
\text { Jendral } \\
\text { Perhubunga } \\
\text { n Udara }\end{array}$} \\
\hline & & $\begin{array}{l}\text { Perkembangan } \\
\text { taxiway }\end{array}$ & & & & \\
\hline & & Perkembangan apron & & & & \\
\hline & & $\begin{array}{l}\text { Perkembangan } \\
\text { bangunan terminal }\end{array}$ & & & & \\
\hline & & $\begin{array}{l}\text { Perkembangan } \\
\text { bangunan operasi }\end{array}$ & & & & \\
\hline & & $\begin{array}{l}\text { Perkembangan lahan } \\
\text { parkir }\end{array}$ & & & & \\
\hline & $\begin{array}{l}\text { Perkembangan } \\
\text { aksesibilitas }\end{array}$ & $\begin{array}{l}\text { Perkembangan akses } \\
\text { multimoda }\end{array}$ & $\begin{array}{l}\text { Apabila } \\
\text { perkembangan } \\
\text { moda } \\
\text { transportasi } \\
\text { yang } \\
\text { terintegrasi } \\
\text { hanya taxi. }\end{array}$ & $\begin{array}{l}\text { Apabila moda } \\
\text { transportasi yang } \\
\text { terintegrasi } \\
\text { mengalami } \\
\text { peningkatan } \\
\text { dengan } \\
\text { terintegrasinya } \\
\text { bandara dengan } \\
\text { moda bus atau } \\
\text { kereta. }\end{array}$ & $\begin{array}{l}\text { Apabila moda } \\
\text { transportasi } \\
\text { yang } \\
\text { terintegrasi } \\
\text { mengalami } \\
\text { peningkatan } \\
\text { dengan } \\
\text { terintegrasinya } \\
\text { bandara dengan } \\
\text { moda bus dan } \\
\text { kereta. }\end{array}$ & $\begin{array}{l}\text { Kasarda, } \\
2008\end{array}$ \\
\hline & $\begin{array}{l}\text { Perkembangan } \\
\text { intensitas } \\
\text { pergerakan }\end{array}$ & $\begin{array}{l}\text { Perkembangan rute } \\
\text { perjalanan }\end{array}$ & $\begin{array}{l}\text { Apabila } \\
\text { intensitas } \\
\text { pergerakan } \\
\text { mengalami } \\
\text { penurunan. }\end{array}$ & $\begin{array}{l}\text { Apabila intensitas } \\
\text { pergerakan tidak } \\
\text { mengalami } \\
\text { penurunan atau } \\
\text { peningkatan } \\
\text { (tetap) }\end{array}$ & $\begin{array}{l}\text { Apabila } \\
\text { intensitas } \\
\text { pergerakan } \\
\text { mengalami } \\
\text { peningkatan. }\end{array}$ & $\begin{array}{l}\text { Kasarda and } \\
\text { Lindsay, } \\
2011\end{array}$ \\
\hline
\end{tabular}




\begin{tabular}{|c|c|c|c|c|c|c|}
\hline \multirow{2}{*}{$\begin{array}{c}\text { Varia } \\
\text { bel }\end{array}$} & \multirow[t]{2}{*}{ Sub Variabel } & \multirow[t]{2}{*}{ Indikator } & \multicolumn{3}{|l|}{ Parameter } & \multirow[t]{2}{*}{ Sumber } \\
\hline & & & Rendah & Sedang & Tinggi & \\
\hline \multirow{3}{*}{ 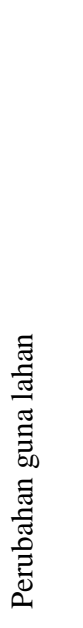 } & $\begin{array}{l}\text { Perubahan } \\
\text { fungsi guna } \\
\text { lahan }\end{array}$ & $\begin{array}{l}\text { Perubahan Guna } \\
\text { Lahan Perdagangan } \\
\text { dan Jasa }\end{array}$ & $\begin{array}{l}\text { Apabila } \\
\text { perubahan } \\
\text { fungsi lahan } \\
\text { yang terjadi } \\
\text { sebesar }<33,3 \%\end{array}$ & $\begin{array}{l}\text { Apabila } \\
\text { perubahan fungsi } \\
\text { lahan yang terjadi } \\
\text { sebesar } 33,3 \% \text { - } \\
66,6 \%\end{array}$ & $\begin{array}{l}\text { Apabila } \\
\text { perubahan } \\
\text { fungsi lahan } \\
\text { yang terjadi } \\
\text { sebesar }>66,6 \\
\%\end{array}$ & $\begin{array}{l}\text { Kasarda and } \\
\text { Lindsay, } \\
2011\end{array}$ \\
\hline & $\begin{array}{l}\text { Perubahan } \\
\text { intensitas guna } \\
\text { lahan }\end{array}$ & KDB & $\begin{array}{l}\text { Apabila } \\
\text { perubahan KDB } \\
\text { yang terjadi } \\
\text { sebesar }<33,3 \%\end{array}$ & $\begin{array}{l}\text { Apabila } \\
\text { perubahan KDB } \\
\text { yang terjadi } \\
\text { sebesar } 33,3 \% \text { - } \\
66,6 \%\end{array}$ & $\begin{array}{l}\text { Apabila } \\
\text { perubahan KDB } \\
\text { yang terjadi } \\
\text { sebesar }>66,6 \\
\%\end{array}$ & \multirow[t]{2}{*}{ Bakar, 2008} \\
\hline & & KLB & $\begin{array}{l}\text { Apabila } \\
\text { perubahan KLB } \\
\text { yang terjadi } \\
\text { sebesar }<33,3 \%\end{array}$ & $\begin{array}{l}\text { Apabila } \\
\text { perubahan KLB } \\
\text { yang terjadi } \\
\text { sebesar } 33,3 \% \text { - } \\
66,6 \%\end{array}$ & $\begin{array}{l}\text { Apabila } \\
\text { perubahan KLB } \\
\text { yang terjadi } \\
\text { sebesar }>66,6 \\
\%\end{array}$ & \\
\hline
\end{tabular}

